Ministerstwo Nauki

i Szkolnictwa Wyższego

Digitalizacja archiwalnych numerów czasopisma naukowego Analecta Cracoviensia 1-24 (1969-1992)

i ich publikacja w otwartym dostępie - zadanie finansowane w ramach umowy 672/P-DUN/2017 ze środków

Ministra Nauki i Szkolnictwa Wyższego przeznaczonych na działalność upowszechniającą naukę

\title{
POLSKIE STARANIA O WPROWADZENIE DO LITURGII KOS̃CIOŁA ŚWIĘTA SERCA JEZUSA Z WŁASNĄ MSZĄ S̃W. I OFICJUM
}

W wielkim objawieniu w Paray-le-Monial w r. 1675 prosił Chrystus o ustanowienie uroczystości Najświętszego Serca, którą należało obchodzić w piątek po oktawie Bożego Ciała. Święto zaś w konsekwencji domaga się własnego formularza miszalnego oraz oficjum brewiarzowego. Myślała już o tym św. Małgorzata Maria Alacoque. „Umarłabym zadowolona - pisała w styczniu 1689 r. - gdybym doczekała się zatwierdzenia przez Stolicę świętą mszy św. o tym godnym uwielbienia Sercu" 1 .

Pierwsze starania $\mathrm{w}$ tej sprawie podjął klasztor wizytek w Dijon, słynący $z$ gorliwości $w$ rozpowszechnianiu kultu. Jedna $z$ sióstr, Joanna Magdalena Joly, ułożyła formularz mszy św., który poprawił i uzupełnił ks. M. Charollais, spowiednik zakonnic w tym mieście. Kongregacja Obrzędów nie zatwierdziła jednak tego tekstu, ponieważ prośbę do Rzy$\mathrm{mu}$ wysłano $\mathrm{z}$ pominięciem miejscowego ordynariusza. Zwrócono się więc do Kurii w Langres, skąd nadeszła odpowiedź przychylna. W pierwszy piątek lutego 1689 r., w oktawę św. Franciszka Salezego, w klasztorze Nawiedzenia w Dijon została po raz pierwszy odprawiona msza św. o Najświętszym Sercu, rozpoczynająca się od słów: „Gaudeamus omnes in Domino" 2 .

W r. 1692 wizytki przedstawiły Stolicy Apostolskiej nową prośbę. Starania zakonnic poparł kard. de Forbin-Janson (1624-1713), ambasador Ludwika XIV w Watykanie oraz zdetronizowana królowa Anglii Maria Eleonora d'Este, żona Jakuba II Stuarta. Z nabożeństwem do Najświętszego Serca zaznajomił królowę Klaudiusz la Colombière SJ, jej spowiednik. Przebywając na wygnaniu w Saint-Germain-en-Laye napisała Maria do papieża Innocentego XII list, prosząc o zatwierdzenie dla klasztorów wizytek święta Serca Jezusa w piątek po oktawie Bożego

1 M. Gauthey, Vie et oeuvres de sainte Marguerite-Marie Alacoque. T. 2, Paris 1920,425 .

2 A. Hamon, Histoire de la dévotion au Sacré Coeur. T. 1, Paris 1923, $400 \mathrm{nn}$. 
Ciała. Wniesioną sprawę referował w Kongregacji Obrzędów kard. Forbin-Janson. Postulator Frigidiano Castagnori przedstawił na piśmie szereg racji przemawiających za ustanowieniem uroczystości, podkreślając przy tym fakt, że zakonnice Nawiedzenia, zgodnie $\mathrm{z}$ duchem założyciela św. Franciszka Salezego, pielęgnują ten kult od dawna. Promotor wiary Prosper Bottini, abp Myry, przyznał, że prośba jest słuszna, ale wysunął przeciw niej kilka zastrzeżeń, akcentując szczególnie nowość kultu. W swojej argumentacji oparł się na autorytecie św. Bernarda, który w liście do kanoników lyońskich ganił wprowadzanie nowych świąt wbrew dawnemu zwyczajowi Kościoła. Postulator umiejętnie rozwiązał trudności promotora wiary, wykazując, że poszczególne nabożeństwa powstawały w chrześcijaństwie stopniowo i każde z nich musiało być na początku nowością. Na postawiony zarzut $\mathrm{z}$ pism św. Bernarda odpowiedział, że nie samo nabożeństwo jako takie spotkało się $\mathrm{z}$ naganą, ale samowolne ustanowienie święta, które wprowadzono bez zgody Rzymu ${ }^{3}$.

Mimo tych wyjaśnień Kongregacja Obrzędów prośby nie spełniła. W okresie, kiedy wprowadzano w Kościele wiele nowych nabożeństw, wskazana była daleko posunięta ostrożność. Po rozpatrzeniu sprawy wydano 30 marca 1697 r. dekret Gebennen, zezwalający jedynie kapłanom odprawiającym msze św. w kościołach wizytek w piątek po oktawie Bożego Ciała na używanie formularza mszalnego o Pięciu Ranach Chrystusa Pana. Decyzję powyższą Innocenty XII zaaprobował 3 kwietnia tegoż roku ${ }^{4}$. Z negatywną odpowiedzią spotkały się także prośby urszulanek z Wiednia w r. 1697 oraz wizytek w r. 1705.

Nowe starania podjęto w Rzymie za pontyfikatu Benedykta XIII. W imieniu klasztorów francuskich pisały do papieża wizytki z Paray-le-Monial, wysłał swą prośbę Henryk de Belsunce, bp Marsylii, wpłynęły do Stolicy Apostolskiej również listy z Polski.

\section{POLSKIE STARANIA W LATACH $1726-1728$}

Pierwszą prośbę o zaprowadzenie święta Serca Jezusa wysłał do Rzymu Konstanty Szaniawski, biskup krakowski. W liście z 6 maja 1726 r. donosił on papieżowi, że $\mathrm{w}$ całym Królestwie Polskim kwitnie stałe nabożeństwo do Najświętszego Serca, że ludzie pobożni pragną dalszego rozwoju tego kultu i dlatego, zgodnie z życzeniami wiernych, prosi Ojca św., ,aby w pasterskiej łaskawości i mocą swej pełnej apostolskiej władzy ustanowił święto Najświętszego Serca Jezusa dla całego Kościoła

${ }^{3}$ N. Nilles, De rationibus Festorum Sacratissimi Cordis Jesu et Purissimi Cordis Mariae. T. 1, Oeniponte 1875, $20 \mathrm{nn}$.

${ }_{4}$ Benedicti XIV, pont. opt. Max. olim Prosperi cardinalis de Lambertinis opus De servorum Dei beatificatione et canonisatione. T. 10, Neapoli 1775, 95. 
z osobną mszą św. i oficjum"5. Biskup wspomniał jeszcze o wizytkach, które z wielką gorliwością szerzą ten kult w Polsce. Słowa Szaniawskiego nie były wcale przesadą. Wizytki $\mathrm{w}$ tym czasie zakładały przy swoich kościołach bractwa Serca Jezusa, wzmogły także działalność wydawniczą. Szczególną rolę w szerzeniu tej czci zaczął odgrywać klasztor krakowski, zwłaszcza za przełożeństwa matki Teresy Franciszki Szembekówny (1714-1720). Konstanty Szaniawski darzył matkę Teresę dużym poważaniem. W czasie choroby kilka razy ją odwiedził, a ,kiedy go już pewnego dnia nie poznała, z żalu zapłakał" 6. Potem prowadził jej kondukt pogrzebowy. Poprzez Teresę Szembekównę wiązała biskupa z klasztorem żywa więź przyjaźni. Jest zatem rzeczą prawdopodobną, że to właśnie pod wpływem wizytek Szaniawski wysłał swoją prośbę do Rzymu. Siostry dowiedziawszy się, że klasztory Nawiedzenia we Francji podjęły nowe starania o wprowadzenie święta (list $\mathrm{z}$ dnia 6 czerwca 1725 r. do Benedykta XIII), postanowiły dołączyć się do tej akcji, prosząc biskupa o poparcie. W rok później Szaniawski skierował do papieża wspomniany list. Prośbę biskupa krakowskiego poparł August II, który 15 maja 1726 r. wysłał z Warszawy do Benedykta XIII oddzielne pismo, stwierdzając, że Królestwo Polskie doznaje szczególnej opieki Najśw. Serca, że specjalnym nabożeństwem odznacza się zarówno on sam, jak i caly naród, że pragnie, aby papież rozszerzył ten kult na cały świat dla pociechy duchowej króla i jego poddanych, dla zbudowania wiernych innych krajów, dla uzyskania błogosławieństwa Najświętszego Serca ${ }^{7}$.

Pod względem treści oba listy są podobne do siebie. Uderza także zbieżność dat ich wysłania do Rzymu. Odstęp czasowy między jednym a drugim pismem wynosi zaledwie 10 dni. August II, podobnie jak Szaniawski, darzył siostry Nawiedzenia życzliwością. Pewien drobny szczegół zanotowany w Księdze Wpisowej do bractwa krakowskiego wskazuje na ich wzajemne powiązania w sprawie kultu Serca Jezusa. Kiedy w r. 1718 wprowadzały siostry do swojego kościoła w Krakowie bractwo, na jednej $\mathrm{z}$ bram triumfalnych umieściły portret monarchy $\mathrm{z}$ napisem: „Regi cordium cor suum et regna Rex Augustus” 8.

Wizytki, zabiegając w Rzymie o ustanowienie święta, wiedziały dobrze, że w Kościele wprowadzenie nowej uroczystości następuje zwykle nie z inicjatywy Stolicy Apostolskiej, ale na skutek licznych i natarczywych próśb wiernych, zwłaszcza osób wpływowych i cieszących się autorytetem. Toteż pragnąc zrealizować życzenia Serca Jezusa wyrażone w Paray-le-Monial, szukały poparcia u panujących i biskupów. Siostry

5 N. Nilles, j.w., 33 n.

6 Historia krakowskiego klasztoru sióstr Nawiedzenia N.M.P. (PP. Wizytek) zaczerpnięta ze starych Kronik i aktów, Kraków 1931, 64 n.

7 N. Nilles, j.w., 34 n.

3 Opisanie Introdukcyi Bractwa Nayslodszego Serca Pana Jezusowego. Rkps Archiwum klasztoru wizytek (Kraków). 
krakowskie miały do króla dojście łatwe. August II, dążąc do złamania potęgi wielkich dworów, tworzył stronnictwo złożone z ludzi skromnego pochodzenia i majątku. W ten sposób doszli do znaczenia Szembekowie, zwłaszcza Jan i Krzysztof. Jan Szembek, kanclerz Wielki Koronny, był bratem wizytki Teresy Szembekówny i wraz z żoną Ewą należał do bractwa Serca Jezusowego w Krakowie 9. Rodzina Szembeków otaczała troskliwą opieka nie tylko klasztor sióstr Nawiedzenia, ale również bractwo. Przełożona, Józefa Franciszka Duninówna, pisząc po śmierci matki Teresy życiorys zmarłej, zaznacza, że wydając kssiążki o Sercu Pana Jezusa, nie obciążała kasy klasztornej, ponieważ wszelkie koszta $\mathrm{z}$ tym związane pokrywali jej bracia. Robili to „dla ukontentowania jej nabożeństwa”, a ona „często się im dlatego naprzykrzała” ${ }^{10}$. Księgi rachunkowe notują spore sumy, jakie Jan Szembek, znany ze swej hojności, ofiarowywał klasztorowi ${ }^{11}$. Być może więc, że wizytki za pośrednictwem Szembeków, szukały poparcia królewskiego dla załatwienia sprawy kultu Serca Jezusa u Stolicy Apostolskiej. August II tym chętniej spełnił życzenia sióstr, ponieważ po nawróceniu chciał dać papieżowi dowody swej pobożności, gorliwości i przywiązania do wiary katolickiej.

Głównym postulatorem i obrońcą kultu Serca Jezusa w Rzymie był wtedy J. Galliffet SJ, wielki apostoł Najśw. Serca z czasów Małgcrzaty Marii. Jako asystent generała zakonu przebywał on stale $\mathrm{w}$ wiecznym mieście i miał ułatwiony dostęp do najwyższych dostojników kościelnych. W r. 1725 wydał obszerne dzieło De cultu Sacrosancti Cordis Dei ac Domini nostri Jesu Christi, które dedykował papieżowi Benedyktowi XIII. Miał nadzieję, że książką przyczyni się do lepszego zrozumienia kultu i pomoże odpowiednim władzom podjąć pozytywną decyzję w sprawie ustanowienia święta. Praca J. Galliffeta zyskała wielkie uznanie promotora wiary P. Lambertiniego, późniejszego papieża Benedykta XIV.

Przedłożone prośby rozpatrywała Kongregacja Obrzędów 15 lutego 1727 r. Z jej protokołu dowiadujemy się, że na posiedzeniu omawiano problem zatwierdzenia mszy św. i oficjum o Najświętszym Sercu na piątek po oktawie Bożego Ciała dla całego Królestwa Polskiego, dla diecezji marsylskiej oraz dla kościołów zakonu Nawiedzenia. Stało się to na skutek usilnych nalegań króla polskiego. Po dyskusji, którą zagaił kardynał Hannibal Albani, postanowiono sprawę odłożyć ad acta i powiadomić o tym postulatorów ${ }^{12}$. Powyższą decyzję podjęto w tym celu,

9 Księga Wpisowa. Rkps Archiwum klasztoru wizytek (Kraków).

10 Księga ślubów. Rkps Archiwum klasztoru wizytek (Kraków).

11 Księga Percepty y expensy Roczney poczętey w roku teraźnieyszym $1685 w$ klasztorze naszym krakowskim zakonu Nawiedza Nayświętszey Panny. Rkps Archiwum klaszoru wizytek (Kraków).

12 Decreta Sacrae Rituum Congregationis ab anno 1727 ad annum 1729, f. 32 (rkps Archivum Sacrae Congregationis pro Causis Sanctorum, Roma). 
aby Prosper Lambertini, promotor wiary, mógł zebrać zarzuty przeciw ustanowieniu święta. Wysunięte zastrzeżenia, tzw. Animadversiones, przekazał Lambertini na piśmie J. Galliffetowi. W liście do biskupa J. Langueta (21 kwietnia 1727 r.) J. Galliffet zaznacza, że w maju praca będzie skończona. Wówczas oba pisma (Animadversiones oraz Responsio ad animadversiones) będą wydrukowane, rozdane zainteresowanym osobom i prośba o ustanowienie święta $\mathrm{z}$ własną mszą i oficjum znów wejdzie pod obrady Kongregacji ${ }^{13}$.

Wśród zarzutów promotora wiary, na pierwszym miejscu znajdowała się trudność wysunięta już kiedyś przez Prospera Bottiniego, a mianowicie - nowość święta. Nieufność Lambertiniego wywołał także lęk przed niebezpiecznym precedensem polegającym na tym, że jeżeli pozwoli się na kult Serca Jezusa, to wierni z kolei mogą żądać ustanowienia innych świąt dla uczczenia poszczególnych części ciała Chrystusa, względnie osób i tajemnic związanych $\mathrm{z}$ życiem Zbawiciela. Poza tym, według promotora wiary, poszczególne święta powszechne lub lokalne ku czci Chrystusa miał ustanawiać Kościół zwykle na skutek jakiegoś znacznego cudu (Boże Ciało), albo też dla uczczenia narzędzi Jego męki (święto włóczni) względnie Jego relikwii (święto znalezienia Krwi Przenajświętszej). Tymczasem w wypadku święta Serca Jezusa cudu nie było lub nie został udowodniony. Samo zaś święto nie dotyczy ani narzędzi męki, ani relikwi Pańskich. W Kościele istnieje zresztą już wiele świąt dla uczczenia ludzkiej natury Chrystusa i nie potrzeba zabiegać o dodatkową uroczystość tym bardziej, że nie uhonorujemy nią żadnej nowej tajemnicy z życia Zbawiciela. Dotychczasowe prośby Kongregacja Obrzędów odrzucała. Promotor wiary podważył także argumentację postulatora, w której nawiązywał on do objawień Małgorzaty Marii Alacoque, wykazując, że nie można się na nich opierać, ponieważ nie zostały jeszcze zbadane przez Kościół ${ }^{14}$.

Do tych zarzutów przedstawionych na piśmie i na które J. Galliffet odpowiedział, Lambertini w czasie posiedzenia Kongregacji 12 lipca dorzucil ustnie nową trudność. Miała ona - jak się zdaje - największy wpływ na decyzję członków Kongregacji. Zarzucił mianowicie postulatorom, że uważają serce za zmysłowy współczynnik, organ (conprincipium) wszystkich cnót i uczuć oraz za ośrodek wszelkich radości i cierpień, podobnie jak oko jest siedliskiem wzroku, a ucho słuchu. Tymczasem współcześni filozofowie siedzibę miłości, nienawiści i innych wzruszeń

13 A. Hamon, j.w., t. 4, 46.

14 Polona institutionis festi sive Concessionis Officii et Missae propriae in honorem sacrosancti Cordis Domini Nostri Jesu Christi Animadversiones Rm Fidei Promotoris, w: Sacra Rituum Congregatione Emo D. Card. S. Clementis ponente POLONA concessionis officii et Missae propriae in Honorem Sacrosancti Cordis Domini Nostri Jesu Christi positio, Romae 1727, B-B5. 
widzą nie w sercu lecz w mózgu. Dopiero za pośrednictwem nerwów zostają one przeprowadzone do serca. Na poparcie swojego zdania powołał się Lambertini na powagę Muratoriego i wyraził opinię, że nie należy się przychylać do prośby, która opiera się przede wszystkim na przekonaniu starych filozofów, niezgodnym z nowymi poglądami, tym bardziej że Kościół nie wypowiedział jeszcze swojego zdania w tej sprawie.

Kierując się tymi racjami Kongregacja odpowiedziała na przedstawione prośby: „non proposita" 15 . Sformułowanie to oznaczało w języku kurii odłożenie sprawy, a zarazem było ostrzeżeniem pod adresem postulatorów, aby powstrzymali się od dalszych starań, ponieważ problem zawiera zbyt wiele trudności. J. Galliffet uważał jednak, że sprawa jest do wygrania, tylko należy jej bronić lepszymi argumentami. W tym celu opracował stosowny traktat (tzw. Novae observationes) i wręczył go członkom Kongregacji ${ }^{16}$.

Dokument liczył 90 stron in folio i naświetlił takie problemy, jak rozwój kultu, jego natura, ustanowienie święta, godność serca ludzkiego i jego wpływ na wszystkie działania człowieka, rana Najśw. Serca, świętość nabożeństwa. W dalszej kolejności J. Galliffet odpowiedział na zarzuty promotora wiary oraz przytaczał różne zdarzenia z życia świętych, celem głębszego omówienia dyskutowanej tezy o sercu jako organie miłości i innych uczuć ludzkich. Pod koniec lipca 1729 r. sprawa ustanowienia święta Serca Jezusa z własną mszą i oficjum znów weszła pod obrady oficjalnych czynników Kościoła. Członkom Kongregacji Obrzędów przedstawił ją kard. Hannibal Albani w obszernym piśmie, które M. Nilles nazwal Novum Memoriale sub auspiciis Regis Poloniae et Episcopi Cracoviensis oblatum ${ }^{17}$.

Treść dokumentu ujęta została w pięciu paragrafach. Pierwszy, o charakterze opisowym, przedstawia krótko rozwój kultu, aby wykazać, że prośba nie dotyczy rzeczy w Kościele nowej, jak to już wiele razy zarzucano postulatorom. Stolica Apostolska - stwierdza pismo - od 35 lat, podczas pontyfikatu czterech papieży (Innocenty XII, Klemens XI, Innocenty XIII, Benedykt XIII) pozwalała na obchodzenie święta Serca Jezusa, godząc się na zakładanie licznych bractw zarówno przy kościołach zakonnych, jak i parafialnych. Ich liczba, jak wykazują katalogi, sięga 349 i są one rozsiane prawie we wszystkich królestwach i znaczniejszych diecezjach. Konsekwentnie i święto Serca Jezusa obchodzi się tutaj bardzo uroczyście, w piątek po oktawie Bożego Ciała, za zgodą bis-

15 Decreta Sacrae Rituum Congregationis f. 105.

16 A. Hamon, j.w., t. 4, 47.

17 N. Nilles, j.w., $65 \mathrm{nn}$. 
kupów, a niekiedy $z$ ich nakazu. Prośba dotyczy więc zatwierdzenia mszy św. i oficjum dla święta szeroko w Kościele rozpowszechnionego, które nawet Stolica św. obdarowała licznymi odpustami. Przez wprowadzenie jednolitego formularza znikną formularze partykularne, a samo święto obchodzić będą wierni $\mathrm{z}$ większym pożytkiem i zbudowaniem.

Następne dwa paragrafy przedstawiają doniosłość, świętość i wielką godność sprawy, o którą zabiegają postulatorzy. Ustanowienia święta domagają się dwaj królowie (polski i hiszpański), biskup Krakowa i Marsylii, zakon Nawiedzenia, co najmniej 117 arcybiskupów i biskupów europejskich, 349 bractw skupiających $\mathrm{w}$ swoich szeregach wielką liczbę członków, 90 kościołów metroplitalnych, katedralnych, kolegiackich, parafialnych oraz 223 kościoły zakonne. Sprawa dotyczyła także Stolicy Apostolskiej, która potwierdzając bractwa i udzielając im odpustów, sama przyczyniła się do rozwoju kultu Serca Jezusowego na całym świecie. W tej sytuacji ewentualna odmowa Kościoła wywołać by mogła zgorszenie wśród wiernych, a nawet podejrzenie, że w tym nabożeństwie kryje się jakiś błąd. Swiętość i godność kultu wynika z jego przedmiotu i celu. Serce Zbawiciela złączone z duszą i Boską Osobą Słowa stanowi przedmiot najświętszy i najgodniejszy, uznany przez tradycję, potwierdzony w licznych objawieniach przez samego Chrystusa. Przedziwny rozwój tego nabożeństwa ma również wielką wymowę, ponieważ jest rzeczą niemożliwą, żeby kult niezgodny z prawdziwą religią i pobożnością, tak szybko się rozrastał $\mathrm{w}$ Kościele i to za zgodą biskupów i cichą aprobatą papieży.

Omawiając w paragrafie czwartym, najobszerniejszym, przedmiot kultu (fizyczne Serce Zbawiciela jako szczególny znak Jego milości), dokument równocześnie przezwycięża wysuniętą ustnie przez Prospera Lambertiniego na posiedzeniu Kongregacji 12 lipca 1727 r. trudność, że prośba postulatorów opiera się na poglądzie filozoficznie kontrowersyjnym. Dokument wykazuje, że wewnętrzny udział cielesnego serca w stanach uczuciowych i konsekwentnie w miłości, jest faktem uznanym przez wszystkich. Kwestionowany jest tylko sposób tego uczestnictwa. Jedni twierdzą, że serce uczestniczy bezpośrednio jako cielesny organ aktywności uczuciowej, a drudzy utrzymują, że tylko pośrednio, ponieważ źródłem działalności afektywnej najpierw jest mózg, a dopiero za pomocą nerwów „dotyka” ona również serca. Tymczasem przedstawiona Stolicy Apostolskiej prośba nie opiera się ani na jednym, ani na drugim wątpliwym wyjaśnieniu, ale wyłącznie na fakcie, którego nikt nie podważa.

Odpowiadając w paragrafie piątym na różne trudności, wysuwane przeciw czci Najświętszego Serca, dokument podkreśla, że dotyczą one nie tyle samego kultu, ile raczej sposobu jego wyjaśnienia. Podobne 
trudności można wysunąć także przeciw innym nabożeństwom, już od dawna przyjętym w Kościele.

Nietrudno zauważyć, że przedstawione pismo opierało się całkowicie na Novae observationes J. Galliffeta oraz na jego książce De cultu sacrosarcti Cordis Dei ac Domini nostri Jesu Christi. Autor wiele razy powołuje się na jedną i drugą pozycję, dając odnośniki do rozdziałów, w których dana kwestia omówiona została szerzej. Wszystko wskazuje na to, że autorem tym był sam J. Galliffet. Natomiast $\mathrm{z}$ tytułu pisma: $P_{0-}$ lona concessionis officii et Missae propriae in honorem sacrosancti Cordis D. N. Jesu Christi, wynika wyraźnie, że dokument dotyczył sprawy polskiej. W rzetelnie pogłębionym wywodzie J. Galliffet chciał przekonać członków Kongregacji Obrzędów o słuszności, ważności i świętości sprawy, wysuwanej przez Augusta II i Konstantego Szaniawskiego. Nie jest wykluczone, że J. Galliffet wnosząc to pismo do Kongregacji, kontaktował się $\mathrm{z}$ oboma dostojnikami polskimi ${ }^{18}$. Przedstawioną prośbe Kongregacja Obrzędów rozważała 30 lipca 1729 r. i odpowiedziała ,negative" 19. Sprawa, zdaniem ojców, nie była jeszcze w pełni dojrzała ${ }^{20}$.

W ten sposób zakończył się pierwszy etap polskich starań o zaprowadzenie mszy św. i oficjum o Sercu Jezusa. Nie pomniejszając zasług zakonu Nawiedzenia, biskupa Marsylii, króla Hiszpanii, a przede wszystkim J. Galliffeta, który był teologiem i obrońcą kultu w Rzymie, trzeba przyznać, że ważną rolę odegrały $w$ tych staraniach listy Konstantego Szaniawskiego i Augusta II. Poparli oni sprawę zaraz $w$ pierwszej fazie, dzięki czemu mogła się ona rozwijać dalej. Wszystkie protokoły z posiedzeń Kongregacji noszą nagłówki Polona. Źródła rzymskie na pierwszym miejscu wymieniają prośbę Polski, a dopiero później wspominają o suplikach $z$ diecezji marsylskiej i zakonu Nawiedzenia.

Petycje polskie różniły się także od pozostałych próśb. Podczas gdy wizytki starały się o uzyskanie pozwolenia na mszę i oficjum tylko dla klasztorów swojego zakonu, biskup Henryk Belsunce dla diecezji marsylskiej, a król Filip dla królestwa Hiszpanii, to Konstanty Szaniawski i August II domagali się od papieża ustanowienia święta dla całego Kościoła.

Podjęte starania nie zostały jednak ukoronowane powodzeniem głównie dlatego, że kult Serca Jezusa opierano na objawieniach prywatnych Małgorzaty Marii, nie sprawdzonych jeszcze przez Kościół oraz że nie wyjaśniono dostatecznie problemu zależności uczuć ludzkich od serca.

$18 \mathrm{~J}$. Galliffet był dobrze zorientowany w rozwoju kultu na terenie Królestwa Polskiego i Litwy, czego dowody dał w swojej książce: De cultu sacrosancti Cordis Dei ac Domini nostri Jesu Christi, Romae 1726, 20, $154 \mathrm{nn}$.

19 Decreta Sacrae Congregationis f. 476.

20 Benedicti XIV, j.w., 99. 
Negatywna odpowiedź Kongregacji Obrzędów z r. 1729 opóźniła wprawdzie oficjalne wprowadzenie święta Serca Jezusa, ale nie postawiła tamy rozwojowi kultu. Za zgodą biskupów nabożeństwo zakorzeniało się w poszczególnych diecezjach dzięki licznym bractwom. W dobie walki $\mathrm{z}$ jansenizmem gorącego obrońcę znalazł ten kult $\mathrm{w}$ osobie biskupa Jana Languet de Gergy, członka Akademili francuskiej, autora źródłowej biografii Małgorzaty Marii Alacoque.

J. Galliffet, chociaż nie osiągnął upragnionego celu, po powrocie z Rzymu do Lyonu, mimo podeszłego wieku nadal pracował nad rozwojem kultu. Nowe wydanie swojego dzieła, które przygotował w języku francuskim, dedykował królowej Marii Leszczyńskiej, żonie Ludwika $\mathrm{XV}$, gorliwej czcicielce Serca Jezusa, prosząc ją przy tej okazji, by nie szczędziła wysiłków $\mathrm{w}$ celu ustanowienia święta. Ta suplika nie pozostała bez echa. Za pontyfikatu Klemensa XII królowa wszczęła w Rzymie energiczne starania i miała nadzieję, że wysiłki te będą uwieńczone powodzeniem, gdy niespodziewana śmierć papieża w r. 1740 przekreśliła jej plany ${ }^{21}$. Podobne starania podjęła Maria Leszczyniska zaraz po wyborze Benedykta XIV, ale odpowiedź tego papieża na jej list (z 30 października 1740) nie jest bliżej znana. Wiadomo tylko, że posłał on M. Leszczyńskiej ok. 1748 r. większą ilość wyszywanych na płótnie obrazów Serca Jezusa.

Nowe prośby napłynęły do Rzymu za ponityfikatu Klemensa XIII. Orędowała za kultem również Polska. August III, idąc śladami ojca, wszczą na nowo starania listem datowanym w Warszawie 21 sierpnia 1762 r. Wspomina w nim o tragicznej doli narodu, o trudnościach, które wciąż się wzmagają, o klęskach, które jak bicz Boży smagają ludzi wszystkich stanów. Ratunek i ocalenie widzi w kulcie Najświętszego Serca. Prosi więc papieża o zatwierdzenie odpowiedniej mszy św. i oficjum na piątek po oktawie Bożego Ciała dla Polski i Wielkiego Księstwa Litewskiego. Gest ten, zdaniem króla, przyczyni się do rozszerzenia kultu, który przez liczne bractwa i tak już został na tych ziemiach rozpowszechniony. W końcu wyraża ufność, że gorliwość okazana w zaprowadzaniu tego nabożeństwa ubłaga Majestat Boży i odwróci sprawiedliwe kary ${ }^{22}$.

W porównaniu $\mathrm{z}$ dotychczasowymi interwencjami polskimi w Rzymie, list Augusta III zacieśnia prośbę o mszę i oficjum tylko do terytorium naszego kraju. Prawdopodobnie król spodziewał się, że w takim ujęciu będzie ona miała większe szanse powodzenia. Szukając genezy

${ }_{21}$ A. Hamon, jw., t. 4, 89; Année sainte des religieuses de la Visitation sainte Marie, Lyon 1870, 747.

${ }_{22}$ N. Nilles, jw., 97 n. 
pisma Augusta III należy przypuszczać, że król skierował list do Stolicy Apoistolskiej pod wpływem Marii Leszczyńskiej, która po wstąpieniu na tron Klemensa XIII, zdwoiła zabiegi wokół drogiego sobie nabożeństwa. W celu zdobycia poparcia osób wpływowych, musiała inspirować poczynania króla polskiego, z którym łączyła ją bliska koligacja. Mogła to czynić albo osobiście, albo za pośrednictwem córki Augusta III Marii Józefy Saskiej, żony swego syna Ludwika.

Pod wpływem Marii Leszczyńskiej interweniował prawdopodobnie w Rzymie jej ojciec Stanisław, również gorliwy czciciel Najświętszego Senca ${ }^{23}$. W liście pisanym w Lunéville 6 lutego $1763 \mathrm{r}$. donosił papieżowi, że nabożeństwo do Serca Jezusa od dawna rozszerza się w wielu diecezjach Francji i należy sobie życzyć, aby rozwijało się w całym Kościele po uprzednim potwierdzeniu Stolicy Apostolskiej, ponieważ jest to praktyka święta i bardzo pomocna do osiągnięcia zbawienia wiecznego. Następnie wyrażał prośbę, aby Polska i Lotaryngia mogły obchodzić święto Serca Jezusa w piątek po oktawie Bożego Ciała $\mathrm{z}$ odpowiednim formularzem mszalnym i oficjum ${ }^{24}$. Nie jest wykluczone, że na decyzję Leszczyńskich mieli wpływ również jezuici, którzy stale przebywali na dworze Stanisława i Marii jako kapelani i spowiednicy rodziny królewskiej ${ }^{25}$.

Pod koniec swojego listu Stanisław Leszczyński, wspominając osoby, które prosiły ojca św. o rozpowszechnienie nabożeństwa, wymienił oprócz siebie i swoich poddanych również biskupów polskich. Rzeczywiście w latach 1762-1764 wielu pasterzy $\mathrm{z}$ naszego kraju wysłało do Rzymu swoje listy: Wacław Sierakowski, Ignacy Massalski, Hieronim Szeptycki, Adam Grabowski, Walenty Wężyk, Adam Krasiński, Andrzej Bayer, Andrzej Załuski. Ich nazwiska łatwo ustalić na podstawie katalogu petentów, dołączonego do dokumentacji przekazanej członkom Kongregacji Obrzędów w związku z decydującą naradą w 1765 r. ${ }^{26}$. Nie wydrukowano jednak tekstów tych listów. Ostatnia kwerenda przeprowadzona $\mathrm{w}$ archiwum Kongregacji Obrzędów $\mathrm{w}$ związku $\mathrm{z}$ pisaniem tego artykułu nie przyniosła także spodziewanych rezultatów. W tej sytuacji nie jest nam znana bezpośrednia treść tych pism. Opierając się jednak na analizie dotychczasowej korespondencji można przypuszczać, że poszczególne listy biskupów polskich zawierały dwie zasadnicze myśli: $\mathrm{z}$ jednej strony podkreślały rozwój kultu w Polsce, a $\mathrm{z}$ drugiej wyrażały prośbę o potwierdzenie mszy i oficjum. Przypuszczenie to zdaje się potwierdzać końcowa część Memoriału z 1765 r., w którym czytamy,

23 R. Taveneaux, Religijny świat Stanistawa Leszczyńskiego, „Znak” 25 (1974) 1611.

24 N. Nilles, j.w., 97.

25 P. Boyé, Stanislas Leszczyński, Paris 1898, 33 n.

${ }^{26}$ N. Nilles, j.w., 90 n. 
że w Polsce „wszędzie pulsuje dla Najśw. Serca Jezusa najwyższe przywiązanie, nabożeństwo i żarliwa miłość wiernych, która bez wątpienia zapuściła głębsze korzenie w Królestwie Polskim, o czym dowiadujemy się z listów zarówno królów, jak i biskupów tego Królestwa" ${ }^{27}$. Następnie zostały przytoczone wyjąttki z listu biskupa płockiego oraz biskupa warmińskiego, w których jest mowa o rozwoju kultu w Polsce. Cytaty kończa się stwierdzeniem, że podobne dane zawierają listy biskupa wileńskiego, kamienieckiego oraz innych biskupów. $\mathrm{Na}$ taką treść listów naszych biskupów wskazuje również dokumentacja przekazana Kongregacji Obrzędów. Tak więc można powiedzieć, że treść listów biskupów polskich wysyłanych do Stolicy Apostolskiej w latach 1762-1764 jest nam pośrednio znana.

Ukoronowaniem wszystkich próśb, które na przestrzeni przeszło pół wieku napływały do Stolicy Apostolskiej z różnych stron świata, był słynny wspomniany już wyżej Memoriał biskupów polskich, przedłożony Kongregacji Obrzędów na początku 1765 r. Do tego obszernego pisma stanowiącego jakby traktat o początkach, rozwoju i naturze kultu, dołączono obfitą dokumentację tak, że całość obejmowała 132 strony druku in folio ${ }^{28}$.

Genezę i rozkwit kultu naświetlił Memoriał w oparciu o książkę J. Galliffeta. W tej części dokumentu omówione zostały takie zagadnienia jak: historyczne podobieństwo między początkami kultu Bożego Ciała i Serca Jezusa, objawienia św. Małgorzaty Marii Alacoque, stopniowy rozwój nabożeństwa we Francji oraz w innych krajach, szczególnie dzięki bractwom. Następne paragrafy poruszają zagadnienia doktrynalne cytując dosłownie dzieło francuskiego jezuity. Jeszcze raz omówiono szeroko przedmiot kultu (żywe i współczujące Serce Jezusa jest złączone ściśle z duszą i Boską Osobą Zbawiciela, a racją szczególnego uczczenia jest Jego ofiarna miłość ku ludziom, znieważana w Najśw. Sakramencie). Cześć oddawana Najśw. Sercu skierowana jest do Osoby Chrystusa.

27 Tamże, 140.

28 Dokumentacja dołączona do Memoriału zawierała:

a) Sumarium, czyli zbiór Konstytucji Apostolskich wydanych w sprawie odpustów, erekcji bractw, przywilejów ołtarzy itp. Umieszczono tu również listy Filipa V, Augusta II, Augusta III, Stanisława i Marii Leszczyńskich, Franciszka księcia Bawarii, którzy pisali do papieża w sprawie ustanowienia święta ze mszą św. i oficjum.

b) Animadversiones - są to trudności i zarzuty przeciw wniesionej prośbie, które zebrał i przedstawił Kongregacji Obrzędów promotor wiary Prosper Lambertini jeszcze w $1727 \mathrm{r}$.

c) Responsio ad animadversiones - obszerna wyporwiedź adwokata J. Alegianiego na pismo Prospera Lambertiniego. Całość została wydrukowana w Rzymie w 1765 r. pt. Sacra Rituum Congregatione Emo et Emo Domino Cardinali Francisco Albani Episcopo Sabien. Polona concessionis officii et Missae propriae in honorem Sanctissimi Cordis Domini Nostri Jesu Christi positio.

Dokumentacja obrazuje aktualny stan kultu w Kościele. Niektóre źródła podaje N. Nilles w cytowanej wyżej książce. 
Trudność „fizjologiczna”, którą promotor wiary tak mocno podkreślał w r. 1727, została także omówiona w Memoriale. Wewnętrzne doświadczenia człowieka i przeżycia świętych wykazują, że serce ma udział $\mathrm{w}$ stanach uczuciowych. Problemem spornym jest tylko to, czy serce wraz z duszą stanowi zasadę (principium) ludzkich uczuć, czy też jedynie jest narzędziem mniej lub więcej pośrednim. Decyzja Kongregacji nie będzie tej spornej kwestii rozstrzygać. Nie ma w Osobie Chrystusa przedmiotu godniejszego kultu jak Najświętsze Serce, wyrażające tak głęboko i dobitnie Jego miłość i cierpienie. Zniewagi, jakich ono doznaje w Naświętszym Sakramencie, należy zrekompensować przez ustanowienie święta o charakterze wynagradzającym i zadośćczyniącym. Nie będzie to zresztą jakaś nowa uroczystość, ponieważ kult publiczny Serca Jezusa rozwija się w Kościele już od dawna. Dowodem tej czci są kanonicznie erygowane bractwa, udzielane odpusty, poświęcone Najświętszemu Sercu kościoły, kaplice i ołtarze. Przedłożona prośba dotyczy ustalenia i zatwierdzenia oddzielnych formularzy mszy św. i oficjum, dzięki którym kult już istniejący, chętnie przez wiernych praktykowany, aprobowany przez wielu biskupów, a także bezpośrednio przez Stolicę Apostolską, jeszcze bardziej rozpowszechni się w Kościele, przyjmując jednolity charakter.

$\mathrm{Z}$ kolei dokument wykazuje, że kult nie jest sprzeczny $\mathrm{z}$ duchem prawdziwej pobożności, owszem - jest święty i dlatego Kościół może spokojnie udzielić pozwolenia na mszę św. i oficjum. Z doświadczeń minionych wieków wiadomo, że nie było wypadku, aby Stolica św. odrzuciła prośbę dotyczącą czci Pana Jezusa, nawet gdy starała się o to jedna diecezja lub jakaś rodzina zakonna. Obecnie zaś prośbę popierają liczne kraje i zakony. W zakończeniu Memoriał wyjaśnia, że celem szybszego załatwienia sprawy, przedstawiona prośba dotyczy tylko Polski, Królestwa Hiszpanii 29 i Arcybractwa Serca Jezusa w Rzymie oraz podaje dowody, że wymienione społeczności zasługują na tę łaskę. Polacy mają nadto nadzieję, że za pośrednictwem tego kultu, ubogaconego mszą św. i oficjum, ich Ojczyzna wyjdzie z najgorszych niebezpieczeństw i klęsk, jakie ją obeenie trapią. Słowa te były jakby echem listu króla Augusta III z $1762 \mathrm{r}$.

Memoriał został opracowany w dużej części na podstawie dzieła J. Galliffeta. Część wprowadzającą o początkach i rozwoju kultu (§ 1-4) przepisano niemal dosłownie, co zresztą na początku zostało wyraźnie zaznaczone. Memoriał został przygotowany na zlecenie biskupów polskich przez adwokata i liturgistę włoskiego Jana Chrzciciela Alegiani. Taka jest opinia wielu autorów, choć nie podają uzasadnienia swojego stano-

29 Pierwotnie prośba dotyczyła również Hiszpanii. Później na skutek opozycji Don Manuela de Rhoda, ministra króla hiszpańskiego Karola III, pominięto w prośbie ten kraj. - por. Nilles, j.w., 139. 
wiska. Za tym zdaniem zdaje się przemawiać jednak cały szereg racji. Dokument cechuje duża znajomość aktualnych spraw związanych z kultem. Raz po raz odwołuje się do akt znajdujących się w Rzymie. Tylko ktoś przebywający $\mathrm{w}$ wiecznym mieście, mający dostęp do wszystkich źródeł i bacznie śledzący wszystko, co dotyczy kultu, mógł tak dokładnie posługiwać się statystykami oraz znajomością treści listów, napływających do Stolicy Apostolskiej. Niektóre wyrażenia i ujęcia zdają się również wskazywać, że biskupi polscy nie byli bezpośrednimi autorami tego dokumentu. Pod Memoriałem widnieje także podpis Alegianiego. W dokumentacji dołączonej do Memoriału znajduje się między innymi zredagowana przezeń odpowiedź na zarzuty Lambertiniego. Odwołując się w niej do Memoriału, używa sformułowania ,iuxta dicta in nostro Memoriali". Adwokat Alegiani, choć opracował Memoriał na zlecenie biskupów polskich ${ }^{30}$, to jednak wykorzystując dzieło J. Galliffeta oraz listy, napływające do Rzymu w sprawie ustanowienia święta, włączył do sprawy nie tylko samą Polskę, ale również Arcybractwo Rzymskie, a początkowo również Królestwo Hiszpanii.

Decydująca debata nad wniesioną prośbą odbyła się w Kongregacji Obrzędów 26 stycznia 1765 r. Promotor wiary Kajetan Forti ponowił tylko zarzuty Prospera Lambertiniego dotyczące nowości kultu, objawień z Paray-le-Monial oraz przedmiotu uroczystości. Odpowiedział na nie $\mathrm{W}$ obszernym piśmie (21 stron druku in folio) J. Alegiani ${ }^{31}$. Charakterystyczne jest wyjaśnienie, które umieścił na początku swojej wypowiedzi. Chociaż w Memoriale i Summarium - stwierdza - zostały dokładnie naświetlone wszystkie zarzuty przeciw wniesionej prośbie, to jednak celem rozwiązania najmniejszych nawet wątpliwości oraz by słuszność sprawy jeszcze wyraźniej została podkreślona, uważa za rzecz stosowną jeszcze raz omówić po kolei Animadversiones Lambertiniego, które miały taki wpływ na decyzję Kongregacji w r. 1729. Zwraca dalej uwage na fakt, że przyszły Benedykt XIV postawił trudności, aby wywiązać się ze swej funkcji promotora wiary, a nie ze względów obiektywnych. Podczas swojego pontyfikatu zrobił bowiem bardzo wiele dla kultu Najświętszego Serca zatwierdzając bractwa, udzielając im odpustów, obdarzając przywilejami ołtarze, nie sprzeciwiając się świętu Serca Jezusa obchodzonemu na jego oczach w Rzymie. Trudności Lambertinie-

30 Protokół z posiedzenia Kongregacji Obrzędów z 26 stycznia 1765 r. zdaje się potwierdzać fakt, że biskupi polscy mieli także swój udział w powstaniu Memoriatu (choćby tylko przez zlecenie redakcji tego dokumentu Alegianiemu). Czytamy w nim m.in. takie słowa: „Pro gratia que Episcopis Regni Poloniae, qui specialiter supplicarunt nec non pro Archiconfraternitate urbis sub Titulo eiusdem Smi Cordis Jesu..." Decreta Sacrae Rituum Congregationis ab anno 1763 usque ad anuum 1765, f. 211-212 (rkps Archiwum Sacrae Congregationis pro Causis Sanctorum).

${ }_{31}$ Responsio ad animadversiones, w: Sacra Rituum Congregatione Emo et Emo tDomino Cardlinali Francisco Albani Episcopo Sabien, $1 \mathrm{nn}$. 
go dotyczą zresztą nie tyle samej sprawy, ile raczej ustanowienia święta, które przecież de facto od dawna istnieje. W tej sytuacji można by jego zastrzeżenia pominąć, ale dla dobra sprawy należy się nimi znowu zająć.

Do wypowiedzi Alegianiego nawiązał w swoim przemówieniu kard. Jan Franciszek Albani, który referował sprawę kultu liturgicznego na posiedzeniu Kongregacji Obrzędów 26 stycznia 1765 r. Udało się odnaleźć nieznany dotąd tekst tego ciekawego przemówienia wygłoszonego po włosku ${ }^{32}$. Rzuca ono sporo światła na sytuację Kościoła w wieku oświecenia, wskazuje na znaczenie kultu wobec pogłębiającego się procesu sekularyzacji życia i kultury, odznacza się zdrowym krytycyzmem w spojrzeniu na zewnętrzne formy pobożności, często przeradzające się w tanią dewocję i zabobonność. Na wstępie kardynał powiedział, że należy udzielić pozwolenia, o które prosi Królestwo Polskie, ponieważ w wypadku odmowy doszłoby do skandalu. Później jeszcze raz powtórzył to sformułowanie dodając, że ewentualne niespełnienie prośby byłoby może nawet przeciwne Opatrzności Bożej. Następnie naświetlił przedmiot kultu i wykazał, że prośba jest słuszna oraz zgodna $z$ pobożnością chrześcijańską. Jeżeli Kościół zatwierdził inne święta dla uczczenia człowieczeństwa Chrystusa, jeżeli pozwolił na wprowadzenie święta gwoździ, grobu, włóczni, żłobka itp., to tym bardziej powinien zgodzić się na święto Serca Jezusa. W wymienionych świętach oddajemy cześć przedmiotom, które miały tylko zwykky kontakt z Osobą Zbawiciela i w dodatku nie wiadomo, czy są autentyczne. Tymczasem Serce Zbawiciela, o którym wiemy, że istnieje i jest żywe, zasługuje na adorację z samej natury.

W dalszym ciągu swego przemówienia Albani, na podstawie statystyki bractw, kościołów, ołtarzy, udzielonych odpustów itp. wykazuje, że ze względu na wyraźną aprobatę ordynariuszy oraz Stolicy Apostolskiej uroczystość Serca Jezusa jest już świętem publicznym i że prawnie obchodzi je większa część świata chrześcijańskiego. Należy dopełnić je oddzielną mszą św. i oficjum, tym bardziej, że Rzym zatwierdza dla poszczególnych prowincji formularze o błogosławionych, zwłaszcza gdy dany patron był szczególniej z nimi związany. Serce Jezusa z natury swej jest złączone $z$ całym światem, ponieważ wszystkich obejmuje miłością. Mówiąc o aktualności kultu, Albani podkreśla, że jest on niezwykle skutecznym środkiem do ożywienia wiary $w$ narodach $\mathrm{i}$ uświęcenia ludzi, zwłaszcza w obecnych czasach, gdy wątpi się we wszystko. Jeśli odmówi się Polsce własnego formularza, wejdą w użycie inne teksty, dowolnie dobrane, budzące zastrzeżenia, podczas gdy msza św. i oficjum

32 Votum Em. Ponentis Joannis Albani Pro Congregatione S.R. Diei (26) Mensis Januari 1765. Rkps Archivum Directionis Generalis Apostolatus Orationis (Roma). 
z aprobatą Stolicy św. przyczyni się do należytej jedności i porządku w służbie Bożej.

W ostatnim punkcie swojego przemówienia Albani nawiązał do istniejącej opozycji przeciw kultowi. Wykazał przy tym, że wielu ulegając autorytetowi Benedykta XIV zapomina, iż on, pełniąc urząd promotora wiary, miał właśnie za zadanie wysuwać trudności przeciw publicznemu kultowi. Obecnie $z$ pewnością udzieliłby zezwolenia. Nie podważając autorytetu Benedykta XIV, Albani poddaje rzeczowej krytyce wysunięte ongiś przez Lambertiniego argumenty. Wszystkie bazują na powadze św. Bernarda, który wypowiedział się przeciw ustanowieniu święta Niepokalanego Poczęcia. Tymczasem opinia tego doktora Kościoła nie była aż tak wiążąca, skoro Stolica Apostolska wprowadziła to święto. Ponadto w wypadku uroczystości Serca Jezusa jesteśmy w korzystniejszej sytuacji, ponieważ obchodzi się ją już w trzech tysiącach kościołów $i$ to za pozwoleniem ordynariuszy i aprobatą biskupa rzymskiego. Nie chodzi więc wcale o wprowadzenie nowego święta. Następnie przytacza Albani słowa św. Bernarda z jego traktatu o Męce Pańskiej świadczące, jak on wysoko cenił nabożeństwo do Najświętszego Serca.

Odpowiadając w dalszym ciągu na zarzuty, podsunął Albani ciekawą myśl zaczerpniętą od św. Cypriana i św. Augustyna, a mianowicie, że w święcie Serca Jezusowego czcimy pewne specjalne tajemnice, doniosłe w życiu chrześcijańskim: ustanowienie Kościoła - matki naszej oraz ustanowienie Sakramentów śwtętych. Kongregacja Obrzędów po uprzednim zapoznaniu się $\mathrm{z}$ tekstem Memoriału i z dołączoną do niego dokumentacją, a następnie po wysłuchaniu głosu promotora wiary Kajetana Fortiego oraz przedłożenia kard. J. Albaniego, widząc, że „kult Serca Jezusowego jest już rozpowszechniony prawie w całym Kościele [...], że w odprawianiu miszy św. i odmawianiu oficjum o nic innego nie chodzi jak o uzupełnienie kultu już ustanowionego [...], po uprzednim odstąpieniu od decyzji z dnia 30 lipca 1729 r. [...] postanowiła przychylić się do próśb biskupów Królestwa Polskiego i Arcybractwa Rzymiskiego", udzielając zezwolenia na uroczyste obchodzenie święta $z$ własną mszą św. i oficjum ${ }^{33}$. Dekret Kongregacji Obrzędów potwierdził w całej rozciągłości Klemens XIII, 6 lutego 1765 r.

Była to przełomowa data w dotychczasowych dziejach kultu Najświętszego Serca. Po raz pierwszy Kongregacja Obrzędów i papież wyrazili wyraźnie i oficjalnie swoją opinię na temat tego nabożeństwa. Racje zawarte w Memoriale, w odpowiedziach Alegianiego oraz w przemówieniu Albaniego zdołały przekonać najwyższą władzę Kościoła. Przychylając się do wniesionej prośby, Kongregacja nic w Memoriale nie zmieniła, lecz naukę tam przedstawioną wzięła za swoją. Wprawdzie po- 
zwolenie dotyczyło na razie tylko Królestwa Polskiego i Arcybractwa w wiecznym mieście, ale wystarczyło teraz po prostu prosić o zaprowadzenie święta, by Stolica Apostolska bez trudności wyraziła zgodę.

Dekret Kongregacji Obrzędów z r. 1765 był wielkim sukcesem Polski, dawno oddanej kultowi Najświętszego Serca. Wszystkie dokumenty związane $z$ decydującą debatą rzymską, łącznie $z$ votum Albaniego i pozytywną odpowiedzią Kongregacji, świadczą, że w całym procesie chodziło o sprawę polską. Zasługi Polski w tym względzie podkreślił zarówno Pius XII w encyklice Haurietis aquas, jak i Paweł VI w liście apostolskim Investigabiles divitias Christi.

LES DEMARCHES DE LA POLOGNE ET L'INSTAURATION DE LA FETTE LITURGIQUE EN L'HONNEUR DU SACRÉ-COEUR AVEC MESSE ET OFFICE

R és u m é

L'institution d'une fête en l'honneur de Sacré-Coeur avec messe et office propres se posa particulièrement à l'Eglise après les révélations de Paray-le-Monial. Le Christ insistait auprès de sainte Marguerite Marie Alacoque pour que l'on instituât cette solennité et qu'on le célébrât le vendredi suivant l'octave de la Fête-Dieu. La sollicitèrent les Soeurs Visitandines de France, Monseigneur de Belsunce évêque de Marseille et la Pologne.

En 1726 Monseigneur Constantin Szaniawski, évêque de Cracovie et le roi Auguste II en firent la demande à Rome. Les archives des Vistandines de Cracovie permettent d'en étudier la genèse. A Rome le principal apôtre du culte et de l'institution de cette fête fut le Père Joseph de Galliffet, théologien et jésuite.

Les démarches faites de 1726 à 1729 n'aboutirent pas. Les raisons en étaient que l'on fondait le culte du Sacré-Coeur sur les révélations privées de Marguerite Marie alors non confirmées par l'Eglise et que l'on ne voyait pas encore très clairement le ,rapport sentiment et coeur".

Sous le pontificat de Clément XII les demandes affluèrent de nouveau à Rome. La première fut celle du roi Auguste II avec sa lettre du 21 août 1762. De 1762 à 1764 de nombreux évêques écrivirent à Rome. Cela dura cinquante années, couronnées par le célèbre Mémoire des évêques de la Pologne, présenté à la Congrégation des Rites au début de 1765. Il finit par convaincre la Congrégation qui permit enfin la célébration solennelle de la fête du Sacré-Coeur avec messe et office propres. Le décret de la Congrégation, entièrement confirmé par Clément XIII le 6 février 1765, fut un grand succès pour la Pologne, vouée depuis de nombreuses années au culte du Sacré-Coeur.

Tous les documents qui firent la décision dans les débats de Rome montrent que l'affaire concernait proprement la Pologne. Les évêques et les rois de Pologne qui entreprient les démarches à Rome, contribuèrent beacoup au développement du culte du Sacré-Coeur dans l'Eglise. En fait, le décret de la Congrégation des Rites ne concernait que la Pologne et l'Archiconfrérie de la Ville éternelle, mais c'en était assez pour qu'il n'y ait plus qu'à demander au Siège Apostolique la permission de la messe et d' office, ce qu'il accorda sans peine. 